\title{
Perceived threat and benefit toward community compliance of filariasis' mass drug administration in Pekalongan district, Indonesia
}

This article was published in the following Dove Press journal:

Risk Management and Healthcare Policy

\author{
Bagoes Widjanarko 1,2 \\ Lintang Dian Saraswati ${ }^{3}$ \\ Praba Ginandjar ${ }^{3}$ \\ 'Doctoral Program of Public Health, \\ Faculty of Public Health, Diponegoro \\ University, Semarang, Indonesia; \\ ${ }^{2}$ Department of Health Promotion, \\ Faculty of Public Health, Diponegoro \\ University, Semarang, Indonesia; \\ ${ }^{3}$ Department of Epidemiology and \\ Tropical Diseases, Faculty of Public \\ Health, Diponegoro University, \\ Semarang, Indonesia
}

\begin{abstract}
Purpose: Lymphatic filariasis (LF) is a chronic infection of Brugia malayi, Brugia timori, and Wuchereria bancrofti and is a mosquito-transmitted disease. Mass drug administration (MDA) needs to be done annually to control LF and requires adherence of endemic populations to take medication properly. Maintaining high coverage of MDA is a challenge because the activity needs to be done in several years. This study would like to know the compliance of the community in taking medication during MDA periods in Pekalongan district using the health belief model (HBM) approach.
\end{abstract}

Patients and methods: Study population was people living in endemic areas in Pekalongan district, Central Java Province. This was a cross-sectional study. HBM approach was used to analyze community perceived in regard to MDA. There were six of the 19 subdistrict selected as study location, and 100 subjects were selected from each sub-district. Therefore, a total of 600 subjects participated in this study. Data were collected using the structured questionnaire. Data were analyzed quantitatively using the Chi-squared test. Multivariate analysis was used for logistic regression.

Results: Results of this study showed that the mean age of subjects was 38.6 years and had been staying in their villages for more than 30 years. Gender, marital status, history of LF, history of LF in the family, and external cues to action did not relate to MDA compliance. Perceived susceptibility, perceived severity, perceived benefits, and perceived barriers were factors related to the compliance of MDA. After multivariate analysis, the perceived susceptibility did not have relationship with compliance.

Conclusion: This study showed HBM variables, ie, perceived susceptibility, perceived severity, perceived benefit, and perceived barrier associated with the medication adherence of LF. The role of elimination officers was important to increase community knowledge about MDA program and the benefit to control LF disease.

Keywords: lymphatic filariasis, health belief model, medication adherence

\section{Introduction}

Lymphatic filariasis (LF) is a chronic infection of Brugia malayi, Brugia timori, and Wuchereria bancrofti, is transmitted by mosquito, and causes a chronic infection. ${ }^{1,2}$ The distribution of LF includes all tropical and subtropical areas. ${ }^{3,4}$ LF causes the permanent malformation of several body parts and is one of the most important infectious causes of permanent limb disability worldwide. Disability-adjusted life year (DALY) of LF is the highest among all other tropical diseases. ${ }^{5}$ LF is also a major cause of poverty due to the loss of productivity, which eventually becomes an economic burden of family and society. ${ }^{6-8}$
Correspondence: Praba Ginandjar Faculty of Public Health, Diponegoro University, JI Prof Soedarto SH, Kampus UNDIP Tembalang, Semarang 50275, Indonesia

Tel +6281325887942

Fax +62 247460044

Email praba.ginandjar@live.undip.ac.id 
LF does not cause direct mortality, but its severe morbidity and the absence of prompt treatment may cause lifelong disability. ${ }^{9}$ In LF, inflammation and lymphedema are repeated several times in a year. It leads to lymphatic damage and chronic swelling of organs such as the legs, arms, scrotum, vulva, and breasts. ${ }^{2}$ This produces physical burden to the patients and psychosocial stigma both to the patients and their family. Distressing feeling, embarrassment, guilt, behavioral withdrawal, and self-isolation are among characteristics of LF patients, ${ }^{10-13}$ which affect patients' quality of life. ${ }^{12,14,15}$

Mass drug administration (MDA) uses a single dose of diethylcarbamazine citrate (DEC) and albendazole. The aim of MDA is to decrease the microfilaria rate and transmission rate of LF. ${ }^{16}$ However, the drug (DEC) does not have effect to kill adult worm. ${ }^{5}$ Therefore, MDA must be implemented annually for 5 or more consecutive years to all the eligible population, until the adult worms either die or stop producing microfilaria. ${ }^{17}$ MDA coverage needs the compliance of population to take the medication properly. Several areas with poor resources find difficulties to maintain the coverage of MDA in years. ${ }^{18}$ In order to increase MDA compliance, we need to know the determinant of health-seeking behavior in community, both in public and in private health care sectors. ${ }^{19}$ Considering the limitation of MDA, implementation of vector control must be improved as a complement for MDA in order to achieve LF elimination. ${ }^{20}$

Indonesia started to conduct MDA in 106 endemic districts in 2015, including Pekalongan district, Central Java Province. ${ }^{21}$ Pekalongan district reported 62 chronic LF cases, consisted of swelling on legs ( $71 \%$ ), hands (2\%), and genitalia $(17 \%){ }^{22}$ The existence of chronic cases suggests that LF transmission has occurred for years and potentially increased or spread if not treated properly. Pekalongan district had been conducted MDA in endemic subdistricts since 2002-2007. Yet, the microfilaria rate during MDA (2003-2007) remained high, ranged $1.15-3.90 \% .{ }^{22}$ A study in Pekalongan district in 2015 showed that the LF prevalence was $1.98 \%$ in school students and $4.36 \%$ in general population. ${ }^{23}$ Filariasis infection in children is a marker of recent exposure to filarial worms. ${ }^{24}$ This may be related to a lack of community adherence in taking LF drugs during the MDA period.

The success of regular program can decrease the transmission of LF, but unable to eliminate the adult worm. ${ }^{5}$ Therefore, MDA needs to be done annually for minimum 5 years due to the life cycle of worms in the human body. ${ }^{17}$ MDA coverage requires the adherence of endemic populations to take medication properly, which seems difficult for the areas with poor resources. ${ }^{18}$ Therefore, this study would like to explore the community drug adherence during MDA periods in Pekalongan district.

This study uses health belief model (HBM) approach to know the perception of society to LF treatment. The theory of HBM assuming decision toward health action is based on people's opinion concerning with disease effect on health. This theory consists of perceived threat and benefit in complying of suggesting health action. HBM approach is done with the purpose of self-efficacy or self-effort to determine what is good for him/her. Components of HBM theory need to be measured to create a better health education program.

\section{Materials and methods Study design}

This was a cross-sectional study with HBM approach to describe community compliance toward MDA program to decrease the spread of LF

\section{Study site}

Pekalongan district consists of 19 subdistricts. This study was conducted during August 2016 in six subdistricts, ie, Buaran, Kedungwuni, Tirto, Wiradesa, Wonokerto, and Siwalan. The six subdistricts were selected according to the existence of active or chronic LF. Two villages were then selected from each subdistrict. Selection of the village was also based on the existence of active or chronic LF. The LF data were taken from District Health Office of Pekalongan district. The selected villages consisted of Paweden and Kertijayan in Buaran subdistrict, Tangkil Kulon and Capgawen in Kedungwuni subdistrict, Tegaldowo and Jeruksari in Tirto subdistrict, Pekuncen and Karangjati in Wiradesa subdistrict, Sijambe and Bebel in Wonokerto subdistrict, and Sepait and Siwalan villages in Siwalan subdistrict.

\section{Study subject}

The population in this study was aged $\geq 15$ years who lived in endemic area in Pekalongan district, Central Java. The selection of age range was the assumption that they have been able to communicate well. Sampling method used in this study was multistage sampling as seen in Figure 1. At the first level, we determined six subdistricts where LF cases were found. In the second stage, two villages were selected according to the largest number of chronic and active cases. In the third stage, two sub-villages were selected from each village, based on the existence and nonexistence of active or chronic cases LF. At each of sub-village, a cluster random sampling technique was implemented. From each of the 


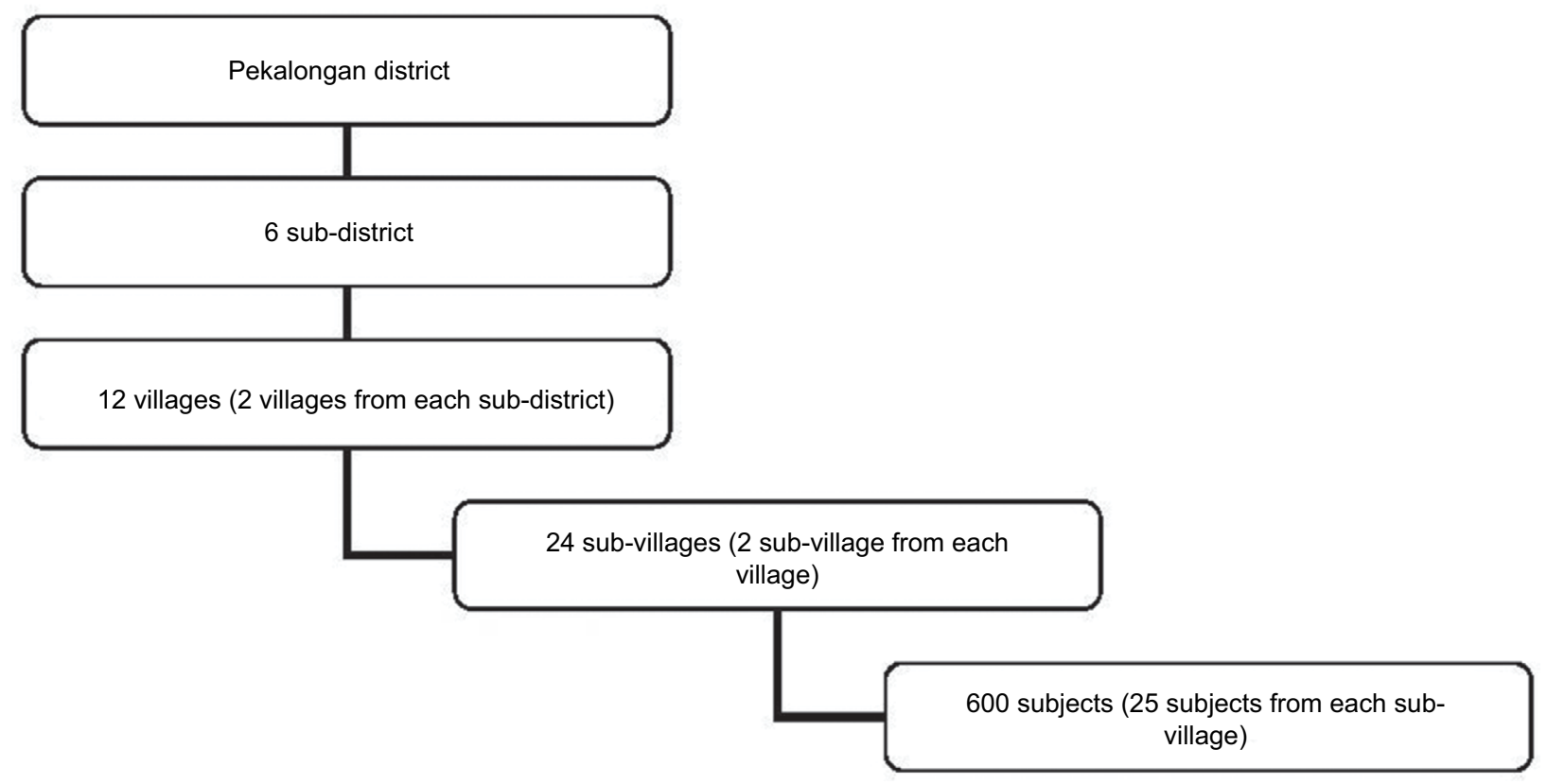

Figure I Selection of the subject.

sub-village, 25 subjects were randomly selected. The subject in each subdistrict, therefore, was 100 persons. Overall, the study subject of the survey was 600 .

\section{Ethical consideration}

Ethical clearance was issued by Ethic Committee of Health Research, Faculty of Public Health UNDIP (113/EC/ $\mathrm{FKM} / 2017)$. All subjects signed informed consent to join the study. A parent or legal guardian signed the informed consent for any participants under the age of 18 years.

\section{Variables}

The variables in this study consisted of characteristics that include name, age, gender, duration of stay in endemic areas, education, employment, income, marital status, number of family members, history of LF, and treatment. HBM variables include the knowledge of LF, perceived susceptibility, perceived severity, perceived benefit, perceived barriers, cues to action, and practice of taking LF medication during MDA period.

Knowledge consisted of LF as hereditary disease, LF as infectious disease, LF transmission, LF prevention, LF treatment, and MDA. Perceived susceptibility is one's belief of the change in getting a certain condition. Perceived susceptibility consisted of awareness that LF may attack all people, selfbelief that he/she is at risk of contracting LF, feel the need to take medicine, and the feeling persists despite not experiencing LF symptoms. Perceived severity is one's belief of how serious a condition and its consequences. Perceived severity consisted of understanding that LF is a severe disease, that one will have severe difficulties in life if exposed to LF, and that LF causes embarrassed in social life, causes a person to be shunned by the social environment, and causes the malformation of several body parts.

Perceived benefit is one's belief in the efficacy of the advised action to reduce the risk or seriousness of impact. Perceived benefit consisted of the feeling that medication during MDA may prevent from LF, a person may avoid LF transmission by taking the medicine, and a person may prevent LF by taking medicine from health officer during MDA, although the medication is done once a year yet it may protect a person from LF. Perceived barrier is one's belief in the tangible and psychological costs of the advised behavior. Perceived barrier consisted of the feeling that a person will experience side effects after taking LF medication, difficulty in reaching drug distribution, difficulty in swallowing medicine, and prohibition from family to take the preventive medicine.

Cues to action are strategies to activate the readiness of a certain condition. Internal cues to action consisted of a person feels of having LF symptoms indicating that he/she suffers from LF, a person feels the need to take the medicine to prevent LF, and a person fears of contracting LF. External cues to action consisted of the role of health officer to remind a person to take the preventive LF medicine, often hear or see announcement to join MDA in order to prevent LF, familiar 
with LF patients who did not take the medicine, a local public figure suggested to follow MDA by taking the medicine.

Each question was scored according to the answer. Positive answers were scored 1, while the negative ones were 0 . Score for each variable was summed up. The total scores of variables perceived susceptibility, perceived severity, perceived benefit, and perceived barrier were then categorized as good ( $>$ median) and poor ( $\leq$ median). Variables internal cues to action and external cues to action were categorized as yes ( $>$ median) and no ( $\leq$ median $)$.

\section{Data collection}

Data were collected using structured questionnaire. The questionnaire included personal characteristics (age, gender, duration of living in endemic area, level of education, level of income, marital status, history of LF, and treatment). The questionnaire was also derived from HBM conceptual framework. The HBM is based on six concepts (perceived susceptibility, perceived severity, perceived benefit, perceived barriers, and cues to action). Adherence toward MDA was also included in the questionnaire.

The structured questionnaire was tested before use to see if the questionnaire can be applied in the field. The test was conducted to learn whether the questions in questionnaire can be apprehended by respondents. Four persons with academic background of public health had selected and trained to be enumerator. One of the investigators (LDS) organized the data collection in the field.

\section{Data analysis}

Data were cleaned by running frequencies to check the error in data entry and completeness of the data. Data were then analyzed using Chi-squared test and logistic regression.

\section{Results}

\section{Characteristics}

Results of this study showed the mean age of subjects was 38.8 years and the mean length of stay in LF endemic area was 34.23 years. Most of the subjects were married, only graduated from elementary school, and unemployed. Proportion of male subjects was almost half of female. Male population usually works at noon, which caused that more female respondents were found. Thirteen subjects were diagnosed as having LF, yet two of them never got treatment (Table 1).

\section{Perceived toward compliance of MDA}

Table 2 shows community perceived toward MDA. There were $88.2 \%$ of respondents agreed that LF can affect every-
Table I Characteristics of study subjects in Pekalongan district, Indonesia, 2017

\begin{tabular}{|c|c|c|}
\hline Characteristics & $n=600$ & $\%$ \\
\hline \multicolumn{3}{|l|}{ Gender } \\
\hline Male & 190 & 31.7 \\
\hline Female & 410 & 68.3 \\
\hline \multicolumn{3}{|l|}{ Education } \\
\hline Not graduated elementary school & 82 & 13.7 \\
\hline Graduated elementary school & 247 & 41.5 \\
\hline Graduated junior high school & 155 & 25.8 \\
\hline Graduated senior high school & 102 & 17.0 \\
\hline College & 14 & 2.3 \\
\hline \multicolumn{3}{|l|}{ Occupation } \\
\hline Unemployed, housewives, students & 237 & 39.5 \\
\hline Labor & 209 & 34.8 \\
\hline Merchant & 57 & 9.5 \\
\hline Tailor & 23 & 3.8 \\
\hline Entrepreneur & 22 & 3.7 \\
\hline Private employees & 18 & 3.0 \\
\hline Fishermen & 10 & 1.7 \\
\hline Retired & 5 & 0.8 \\
\hline Builder & 4 & 0.8 \\
\hline Others & 15 & 2.6 \\
\hline \multicolumn{3}{|l|}{ Marital status } \\
\hline Married & 493 & 82.2 \\
\hline Death divorced & 19 & 3.2 \\
\hline Divorced & 9 & 1.5 \\
\hline Single & 79 & \\
\hline \multicolumn{3}{|l|}{ Age } \\
\hline Mean & 38.8 & \\
\hline Median & 38.0 & \\
\hline Standard deviation & 13.74 & \\
\hline Minimum & 15 & \\
\hline Maximum & 85 & \\
\hline \multicolumn{3}{|l|}{ Length of stay } \\
\hline Mean & 34.2 & \\
\hline Median & 32.0 & \\
\hline Standard deviation & 16.28 & \\
\hline Minimum & $\mathrm{I}$ & \\
\hline Maximum & 85 & \\
\hline
\end{tabular}

body. As much as $87.7 \%$ of respondents felt the need to take LF medication and $86.7 \%$ felt the need to take LF drugs to prevent from the disease. In general, subjects had good perceived susceptibility related to LF (72.7\%). Table 2 also shows that in general, most of the subject had a good perceived severity toward LF (80.7\%). The majority of subjects agreed that LF is a severe disease and will cause difficulty to those who are affected. Most of subjects disagreed that LF causes embarrassed; on the other hand, they agreed LF causing shunned. Most subjects had a good perceived benefit toward MDA (76.8\%). The majority of subjects believed that MDA protects them from LF. They also agreed that MDA removes the fear of being infected by LF. In general, more than half of subjects had good perceived barriers, ie, they did not face 
Table 2 Community perceived toward filariasis in Pekalongan district, Indonesia, 2017

\begin{tabular}{|c|c|c|}
\hline Perceived & $n=600$ & $\%$ \\
\hline \multirow{2}{*}{\multicolumn{3}{|c|}{ Perceived susceptibility }} \\
\hline & & \\
\hline Agree & 529 & 88.2 \\
\hline Disagree & 71 & 11.8 \\
\hline \multicolumn{3}{|l|}{ Subject feels the chances of contracting with LF } \\
\hline Agree & 467 & 77.8 \\
\hline Disagree & 133 & 22.3 \\
\hline \multicolumn{3}{|l|}{ Subject feels the necessity of taking LF medicine } \\
\hline Agree & 526 & 87.7 \\
\hline Disagree & 74 & 12.3 \\
\hline \multirow{2}{*}{\multicolumn{3}{|c|}{$\begin{array}{l}\text { Subject feels the necessity of taking medicine } \\
\text { despite not being sick }\end{array}$}} \\
\hline & & \\
\hline Agree & 520 & 86.7 \\
\hline Disagree & 80 & 13.3 \\
\hline \multicolumn{3}{|l|}{ Perceived susceptibility } \\
\hline Poor & 164 & 27.3 \\
\hline Good & 436 & 72.7 \\
\hline \multicolumn{3}{|l|}{ Perceived severity } \\
\hline \multicolumn{3}{|l|}{ LF is severe disease } \\
\hline Agree & 568 & 94.7 \\
\hline Disagree & 32 & 5.3 \\
\hline \multicolumn{3}{|l|}{ Feeling of will have trouble if infected } \\
\hline Agree & 556 & 92.7 \\
\hline Disagree & 44 & 7.3 \\
\hline \multicolumn{3}{|l|}{ LF causes embarrassment socially } \\
\hline Agree & 562 & 6.3 \\
\hline Disagree & 38 & 93.7 \\
\hline \multicolumn{3}{|l|}{ LF causes shunned } \\
\hline Agree & 507 & 84.5 \\
\hline Disagree & 93 & 5.5 \\
\hline \multicolumn{3}{|l|}{ LF causes ugly appearance } \\
\hline Agree & 563 & 93.8 \\
\hline Disagree & 37 & 6.2 \\
\hline \multicolumn{3}{|l|}{ Perceived severity } \\
\hline Poor & 116 & 19.3 \\
\hline Good & 484 & 80.7 \\
\hline \multicolumn{3}{|l|}{ Perceived benefits } \\
\hline \multicolumn{3}{|l|}{ MDA may prevent LF } \\
\hline Agree & 565 & 94.2 \\
\hline Disagree & 35 & 5.8 \\
\hline \multirow{2}{*}{\multicolumn{3}{|c|}{$\begin{array}{l}\text { With MDA, no need to worry of contracting } \\
\text { LF }\end{array}$}} \\
\hline & & \\
\hline Agree & 486 & 89.0 \\
\hline Disagree & 114 & 19.0 \\
\hline \multicolumn{3}{|l|}{ Taking DEC from health officer protects from } \\
\hline LF & & \\
\hline Agree & 517 & 86.2 \\
\hline Disagree & 83 & 13.8 \\
\hline \multirow{2}{*}{\multicolumn{3}{|c|}{$\begin{array}{l}\text { Once a year medication is enough to protect } \\
\text { from LF }\end{array}$}} \\
\hline & & \\
\hline Agree & 521 & 86.8 \\
\hline Disagree & 79 & 13.2 \\
\hline \multicolumn{3}{|l|}{ Perceived benefit } \\
\hline Poor & 139 & 23.2 \\
\hline Good & 461 & 76.8 \\
\hline Perceived barriers & & \\
\hline
\end{tabular}

Table 2 (Continued)

\begin{tabular}{|c|c|c|}
\hline Perceived & $n=600$ & $\%$ \\
\hline $\begin{array}{l}\text { Subject will experience health problems when } \\
\text { taking medicine }\end{array}$ & & \\
\hline Agree & $|8|$ & 30.2 \\
\hline Disagree & 419 & 69.8 \\
\hline $\begin{array}{l}\text { Subject experiences difficulty in visiting DEC } \\
\text { distribution center }\end{array}$ & & \\
\hline Agree & 101 & 16.8 \\
\hline Disagree & 499 & 83.2 \\
\hline $\begin{array}{l}\text { Subject experiences difficulty in swallowing } \\
\text { DEC }\end{array}$ & & \\
\hline Agree & 113 & 18.8 \\
\hline Disagree & 487 & 81.2 \\
\hline Family forbids subject to take the medicine & & \\
\hline Yes & 102 & 17.0 \\
\hline No & 498 & 83.0 \\
\hline Perceived barrier & & \\
\hline Poor & 211 & 35.2 \\
\hline Good & 389 & 64.8 \\
\hline Internal cues & & \\
\hline Subject feels experiencing LF sign/symptom & & \\
\hline Yes & 118 & 19.7 \\
\hline No & 482 & 80.3 \\
\hline $\begin{array}{l}\text { Subject feels the need to overcome LF by } \\
\text { taking medicine }\end{array}$ & & \\
\hline Yes & 488 & 81.3 \\
\hline No & 112 & 18.7 \\
\hline Subject is afraid of contracting LF & & \\
\hline Yes & 534 & 89.0 \\
\hline No & 66 & 11.0 \\
\hline Internal cues & & \\
\hline Yes & 500 & 83.3 \\
\hline No & 100 & 16.7 \\
\hline External cues & & \\
\hline $\begin{array}{l}\text { Elimination officers remind subject to take } \\
\text { the medicine }\end{array}$ & & \\
\hline Yes & 542 & 90.3 \\
\hline No & 58 & 9.7 \\
\hline Subjects often get information on MDA & & \\
\hline Yes & 373 & 62.2 \\
\hline No & 227 & 37.8 \\
\hline $\begin{array}{l}\text { Subjects know LF patients who rejects to take } \\
\text { the medicine }\end{array}$ & & \\
\hline Yes & 224 & 62.7 \\
\hline No & 376 & 37.3 \\
\hline $\begin{array}{l}\text { Recommendation of community leader to } \\
\text { take the medicine }\end{array}$ & & \\
\hline Yes & 459 & 76.5 \\
\hline No & $|4|$ & 23.5 \\
\hline External cues & & \\
\hline Yes & 199 & 33.2 \\
\hline No & 401 & 66.8 \\
\hline
\end{tabular}

Abbreviations: LF, lymphatic filariasis; MDA, mass drug administration; DEC, diethylcarbamazine citrate.

any difficulties to participate in the MDA program (64.8\%). They mentioned not to have health problem experience during MDA. Most of them claimed to have family support to take 
the drug. Most subjects (83.3\%) had internal cues to actionrelated LF prevention and taking medicine and more than half of subjects $(66.8 \%)$ did not have external cues to action.

\section{Relationship of perceived factors to the compliance of MDA}

Table 3 shows gender, marital status, history of LF, history of LF in the family, and external cues to action did not relate to MDA compliance $(P=0.605,0.480,0.079,0.314$, and 0.109 , respectively). On the contrary, perceived susceptibility, perceived severity, perceived benefits, and perceived barriers,

Table 3 Factors related to compliance in taking DEC toward mass drug administration in Pekalongan district, Indonesia, 2017

\begin{tabular}{|c|c|c|c|c|c|}
\hline \multirow[t]{2}{*}{ Variables } & \multicolumn{2}{|c|}{ Noncompliance } & \multicolumn{2}{|c|}{ Compliance } & \multirow[t]{2}{*}{$P$-value } \\
\hline & $n=124$ & $\%$ & $n=369$ & $\%$ & \\
\hline \multicolumn{6}{|l|}{ Gender } \\
\hline Male & 39 & 26.7 & 107 & 73.3 & 0.605 \\
\hline Female & 85 & 24.5 & 262 & 75.5 & \\
\hline \multicolumn{6}{|c|}{ Marital status } \\
\hline Married & 105 & 24.4 & 308 & 74.6 & 0.480 \\
\hline Death divorce & 3 & 23.1 & 10 & 76.9 & \\
\hline Divorce & 0 & 0.0 & 7 & 100.0 & \\
\hline Single & 16 & 26.7 & 44 & 73.3 & \\
\hline \multicolumn{6}{|c|}{ Experiencing LF } \\
\hline Yes & 0 & 0.0 & 9 & 100.0 & 0.079 \\
\hline No & 124 & 25.6 & 360 & 74.4 & \\
\hline \multicolumn{6}{|c|}{ Family experiencing } \\
\hline \multicolumn{6}{|l|}{ LF } \\
\hline Yes & 0 & 0.0 & 3 & 100.0 & 0.314 \\
\hline No & 124 & 25.2 & 366 & 74.7 & \\
\hline \multicolumn{6}{|c|}{ Role of elimination } \\
\hline \multicolumn{6}{|l|}{ officer } \\
\hline Not optimum & 85 & 34.4 & 162 & 65.6 & $<0.0001$ \\
\hline Optimum & 39 & 15.9 & 207 & 84.1 & \\
\hline \multicolumn{6}{|l|}{ Perceived } \\
\hline Poor & 49 & 40.5 & 72 & 59.5 & $<0.0001$ \\
\hline Good & 75 & 20.2 & 297 & 79.8 & \\
\hline \multicolumn{6}{|c|}{ Perceived severity } \\
\hline Poor & 37 & 42.0 & 51 & 58.0 & $<0.0001$ \\
\hline Good & 87 & 21.5 & 318 & 78.5 & \\
\hline \multicolumn{6}{|c|}{ Perceived benefits } \\
\hline Poor & 45 & 42.1 & 62 & 57.9 & $<0.000$ I \\
\hline Good & 79 & 20.5 & 307 & 79.5 & \\
\hline \multicolumn{6}{|c|}{ Perceived barriers } \\
\hline Poor & 74 & 45.4 & 89 & 54.6 & $<0.0001$ \\
\hline Good & 50 & 12.5 & 280 & 87.5 & \\
\hline \multicolumn{6}{|c|}{ Internal cues to } \\
\hline $\begin{array}{l}\text { action } \\
\text { Yes }\end{array}$ & 34 & 51.5 & 32 & 48.5 & $<0.0001$ \\
\hline No & 90 & 21.1 & 337 & 78.9 & \\
\hline \multicolumn{6}{|c|}{$\begin{array}{l}\text { External cues to } \\
\text { action }\end{array}$} \\
\hline Yes & 76 & 23.0 & 255 & 77.0 & 0.109 \\
\hline No & 48 & 29.6 & 114 & 70.4 & \\
\hline
\end{tabular}

Abbreviations: DEC, diethylcarbamazine citrate; LF, lymphatic filariasis.
Table 4 Summary of bivariate and multivariate analyses

\begin{tabular}{|l|l|l|l|l|}
\hline Factors & $\begin{array}{l}\text { Crude } \\
\text { OR }\end{array}$ & $\begin{array}{l}\mathbf{9 5 \%} \text { Cl of } \\
\text { crude OR }\end{array}$ & $\begin{array}{l}\text { Adjusted } \\
\text { OR }\end{array}$ & $\begin{array}{l}\text { 95\% CI of } \\
\text { adjusted OR }\end{array}$ \\
\hline $\begin{array}{l}\text { Perceived } \\
\text { susceptibility } \\
\text { Perceived } \\
\text { severity }\end{array}$ & 2.695 & $1.731-4.195$ & 1.363 & $0.784-2.367$ \\
$\begin{array}{l}\text { Perceived } \\
\text { benefits } \\
\text { Perceived } \\
\text { barriers } \\
\text { Internal cues to } \\
\text { action }\end{array}$ & 2.652 & $1.632-4.308$ & 2.454 & $1.374-4.383$ \\
\hline
\end{tabular}

in addition with the role of elimination officers, were factors related to compliance of MDA $(P<0.0001)$. However, after multivariate analysis, Table 4 shows that the perceived susceptibility did not have relationship with compliance ( $P=0.272$; adjusted OR 1.363 ; 95\% CI 0.784-2.367).

\section{Discussion}

The use of HBM to identify community perceived toward MDA was based on the fact that a decision toward health action is based on people's opinion of disease and health. Due to the high cost of MDA program, efforts should be address to evaluate what is the best implementation of the program. This study addressed the role of community perceived in the MDA compliance during the program.

The result of our study was in agreement with several prior studies on the assessment of MDA of LF that showed most respondents were female. ${ }^{25,26}$ Male population usually works at noon, which caused that more female respondents were found. People live in endemic areas for years must aware of LF infection. Risk of LF transmission increases in individual who lived in endemic area for 10 years. ${ }^{27}$ Having a household member with lymphedema, or being a patient him/herself, might affect the awareness of LF risk. ${ }^{28}$ These factors will influence them to comply with the MDA. On the contrary, an individual without personal experience of having LF or having LF patients around may be harder to comply. ${ }^{29}$ In this study, all subjects who had the history of LF or had family member with LF came from endemic area. It is also evident in this study that compliance was higher in endemic areas than in nonendemic ones.

Before MDA, health officer should socialize community that everyone is at risk of contracting LF, despite his/her normal physical appearance. ${ }^{28}$ This may due to the fact that chronic sign of LF occurs 10-15 years after infection. ${ }^{2}$ A previous model showed that people with knowledge about being at risk for LF were also more likely to obey the sug- 
gested treatment. However, the finding was not significant. ${ }^{28}$ This was in accordance with our recent study, which showed that perceived susceptibility did not have relationship with MDA compliance.

A previous study has shown that communities who witness the existence of LF patients in the community will realize that everyone is at risk of contracting the LF and tend to be more obedient to consume the drug. Moreover, the perception that a person may suffer from LF influenced the individual's expression of willingness to participate in the next MDA program. ${ }^{29-31}$ In nonendemic areas, community pays a little attention and gives less priority to LF. Hence, MDA coverage in the area is generally low. People considered LF is not a serious illness and did not feel the need to take medication during MDA. ${ }^{32}$

Subjects in endemic areas were mostly agreed to take DEC annually, while most of subject in nonendemic area were disagreed. Several previous studies revealed that an individual who has positive perceived about the benefit of MDA tends to comply with the medication during MDA. ${ }^{29,33}$ Health promotion programs usually stressed on the advantages of disease's treatment or prevention. In general, health practitioners must think over health as a motivation to achieve compliance. On the contrary, in nonendemic areas, the condition may not applicable. The message about the seriousness of LF seems to be highlighted to encourage people to consume drugs.

Many previous studies revealed that the primary reasons for people to obey the treatment were the hope to be cure from LF, or to avoid LF. Both health and nonhealth benefits are equally influence the compliance of MDA. Therefore, health promotion should not only focus on health but also consider the nonhealth benefits. These include social acceptance, being perceived as healthy family, being a good and obedient citizen, and being wise in preventing LF infection. The appropriate campaigns of MDA may increase the demand for the tablets. ${ }^{33} \mathrm{LF}$ has been shown to be related with the cycle of poverty. Acute attack LF is preventing an individual from working, thereby decreasing income. Patients with chronic LF require regular medical assistance and may suffer from associated stigmas. Therefore, MDA campaign should address the economic and social benefits of treatment. ${ }^{33}$

A study conducted by Cantey et $\mathrm{a}^{28}$ revealed that addressing the barriers against MDA experienced can help to improve compliance. In HBM theory, if the perceived benefit is higher than perceived barrier, people will tend to adhere in taking medicine during MDA program. Several literatures revealed that perceived benefit and self-efficacy were significantly associated with compliance..$^{29,34}$ Study conducted by Adhikari et al proved that almost all of its subjects did not realize that LF patients might be asymptomatic for years. This result was also evidenced in other disease, such as malaria. Complete participation in malaria elimination program was significantly associated with the perceptions that targeted malaria elimination was worthwhile. ${ }^{35}$ They usually started the awareness of LF manifestation when the swollen of the limb or chronic stage has already begun. The unawareness contributes in community perceived that they will not be infected. This will then cause community behavior to not comply in taking medicine. ${ }^{36}$ Our study showed that almost all subjects in nonendemic area did not have internal cues to action that triggered to compliance during MDA. And previous study showed respondents who were visited directly by health officials in their own homes had significantly higher medication adherence than respondents who were not visited by officers. With door-to-door visitation by officers, the community perception of the importance of taking LF medication will increase. ${ }^{36}$

In this study, variables such as characteristics, role of elimination officer, and HBM were tested to find the factors associated with medication adherence in the MDA program. The results are listed in Table 3. There was no difference in adherence based on the characteristics of age (using independent $t$-test, data not shown), gender, marital status, or the presence of LF patients in the family, both overall and after adjusted by the category of endemic. In terms of demographic characteristics, these results were consistent with prior research that age, gender, level of education, illiteracy, and the presence of family members who have lymphedema are not the predictors of medication adherence. ${ }^{28,34}$ Instead, the role of elimination officer and variables of HBM (except external cues to action) were factors associated with LF medication adherence during the implementation of MDA program. Once adjusted based on the endemic and nonendemic, the role of elimination officer and $\mathrm{HBM}$ variables remained related to the medication adherence of LF.

The results of this study support the importance of health promotion to increase community knowledge about the MDA and benefits in the control of LF. HBM variables in this study proved to be related to medication adherence LF. This should be taken into consideration when making the socialization of POMP the community to meet the treatment coverage target of $85 \%$.

This study has some limitations, which have to be pointed out. The retrospective nature of interview in regard to MDA compliance may lead to recall bias. Selection bias may also occur because the locations were selected purposively. 


\section{Conclusion}

In terms of demographic characteristics, age, gender, marital status, and the presence of family members who have lymphedema are not the predictors of medication adherence. While all variables of HBM (except external cues to action) and the role of elimination officer were contributing factors associated with LF medication adherence during the implementation of MDA program.

\section{Acknowledgments}

The authors thank Diponegoro University for research funding (grant number: 276-12/UN7.5.1/PG/2017). The authors also thank all the study participants, District Health Office of Pekalongan, and Public Health Centers for their cooperation in facilitating our study.

\section{Author contributions}

All authors contributed toward data analysis, drafting and revising the paper and agree to be accountable for all aspects of the work.

\section{Disclosure}

The authors report no conflicts of interest in this work.

\section{References}

1. Nutman T. Blood-borne filarial infection: Wuchereria bancrofti, Brugia malayi, Brugia timori, Loa loa, Mansonella perstans and Mansonella ozzardi. In: Gillespie SH, Pearson RD, editors. Principles and Practise of Clinical Parasitology. Chichester, UK: John Wiley \& Sons, Ltd; 2001:433-454.

2. Supali T, Kurniawan A, Partono F. Wuchereria bancrofti, Brugia malayi, Brugia timori. In: Sutanto I, Ismid IS, Sjarifuddin PK, Sungkar S, editors. Parasitologi Kedokteran. 4th ed. Jakarta: Balai Penerbit FKUI; 2011:32-40

3. World Health Organization [webpage on the Internet]. Lymphatic filariasis: situation and trends. WHO Media Centre; 2014. Available from: http://www.who.int/gho/neglected_diseases/lymphatic_filariasis/ en/. Accessed October 7, 2014.

4. World Health Organization [webpage on the Internet]. Lymphatic filariasis: Key facts. WHO Media Centre; 2015. Available from: http:// www.who.int/mediacentre/factsheets/fs102/en/. Accessed November 3, 2015.

5. Ottesen EA, Hooper PJ, Bradley M, Biswas G. The global programme to eliminate lymphatic filariasis: health impact after 8 years. PLoS Negl Trop Dis. 2008;2(10):e317.

6. Okon OE, Iboh CI, Opara KN. Bancroftian filariasis among the Mbembe people of Cross River state, Nigeria. J Vector Borne Dis. 2010;47(2):91-96.

7. Gyapong JO, Gyapong M, Evans DB, Aikins MK, Adjei S. The economic burden of lymphatic filariasis in northern Ghana. Ann Trop Med Parasitol. 1996;90(1):39-48.

8. Ambarita LP, Sitorus H. Studi komunitas nyamuk di Desa Sebubus (daerah endemis filariasis), Sumatera Selatan tahun 2004 [A study on mosquito community in Sebubus village (filariasis endemic area) South Sumatera, 2004]. J Ekol Kesehat. 2006;5(1):368-375.
9. Ottesen EA. Lymphatic filariasis: Treatment, control and elimination. Adv Parasitol. 2006;61:395-441.

10. World Health Organization. Informal Consultation on Evaluation of Morbidity in Lymphatic Filariasis. Geneva, Switzerland: WHO; 1992.

11. Addiss DG, Brady MA. Morbidity management in the Global Programme to Eliminate Lymphatic Filariasis: a review of the scientific literature. Filaria J. 2007;6(1):2.

12. Zeldenryk LM, Gray M, Speare R, Gordon S, Melrose W. The emerging story of disability associated with lymphatic filariasis: a critical review. PLoS Negl Trop Dis. 2011;5(12):e1366.

13. Person B, Bartholomew LK, Gyapong M, Addiss DG, van den Borne B. Health-related stigma among women with lymphatic filariasis from the Dominican Republic and Ghana. Soc Sci Med. 2009;68(1):30-38.

14. Gyapong JO, Webber RH, Morris J, Bennett S. Prevalence of hydrocele as a rapid diagnostic index for lymphatic filariasis. Trans $R$ Soc Trop Med Hyg. 1998;92(1):40-43.

15. Zeldenryk L, Gordon S, Gray M, Speare R, Melrose W. Disability measurement for lymphatic filariasis: a review of generic tools used within morbidity management programs. PLoS Negl Trop Dis. 2012;6(9):e1768.

16. World Health Organization. Global Programme to Eliminate Lymphatic Filariasis; a Handbook for National Elimination Programme. Rome, Italy: WHO Press; 2013. Available from: http://apps.who.int/iris/ bitstream/10665/87989/1/9789241505642_eng.pdf?ua=1. Accessed November 3, 2014.

17. Michael E, Malecela-Lazaro MN, Simonsen PE, et al. Mathematical modelling and the control of lymphatic filariasis. Lancet Infect Dis. 2004;4(4):223-234.

18. Kolaczinski JH, Kabatereine NB, Onapa AW, Ndyomugyenyi R, Kakembo AS, Brooker S. Neglected tropical diseases in Uganda: the prospect and challenge of integrated control. Trends Parasitol. 2007;23(10):485-493.

19. Rahman KMM, Laskar MS, Basu BK, Chowdhury S. Treatment seeking behavior of filariasis patients in a selected endemic area of Bangladesh. Mediscope. 2015;2(2):5.

20. Bockarie MJ, Pedersen EM, White GB, Michael E. Role of vector control in the global program to eliminate lymphatic filariasis. Annu Rev Entomol. 2009;54:469-487.

21. The Ministry of Health Republic of Indonesia. Toward filaria elimination 2020. 1st ed. Jakarta: Infodatin, Ministry of Health; 2014. Indonesian.

22. The Ministry of Health Republic of Indonesia. Filariasis in Pekalongan District Central Java in the year of 2002-2013. Pekalongan Health District Report: 2014. Indonesian.

23. Ginandjar P, Saraswati LD, Suparyanto D, Sakundarno M, Supali T. The Prevalence of Lymphatic Filariasis in Elementary School Children Living in Endemic Areas: A Baseline Survey Prior to Mass Drug Administration in Pekalongan District-Indonesia. IJPH. 47(10):1484-1492.

24. Rebollo MP, Bockarie MJ. Toward the elimination of lymphatic filariasis by 2020: treatment update and impact assessment for the endgame. Expert Rev Anti Infect Ther. 2013;11(7):723-731.

25. Ompusunggu S, Siswantoro H, Purnamasari T, Dewi RM. Pelaksanaan pengobatan masal filariasis d beberapadaerah dengan frekuensi pengobatan berbea. [The implementation of filariasis mass treatment in several regions with different treatment frequencies]. J Penyakt Menular Indones. 2009;1(1):10-19. Indonesian.

26. Roy RN, Sarkar AP, Misra R, Chakroborty A, Mondal TK, Bag K. Coverage and awareness of and compliance with mass drug administration for elimination of lymphatic filariasis in Burdwan District, West Bengal, India. J Health Popul Nutr. 2013;31(2):171-177.

27. Korte RL, Fontes G, Camargo JS, et al. Survey of Bancroftian filariasis infection in humans and Culex mosquitoes in the western Brazilian Amazon region: implications for transmission and control. Rev Soc Bras Med Trop. 2013;46(2):214-220.

28. Cantey PT, Rout J, Rao G, Williamson J, Fox LM. Increasing compliance with mass drug administration programs for lymphatic filariasis in India through education and lymphedema management programs. PLoS Negl Trop Dis. 2010;4(6):e728. 
29. Amarillo ML, Belizario VY, Sadiang-Abay JT, Sison SA, Dayag AM. Factors associated with the acceptance of mass drug administration for the elimination of lymphatic filariasis in Agusan del Sur, Philippines. Parasit Vectors. 2008;1(1):14.

30. Hussain MA, Sitha AK, Swain S, Kadam S, Pati S. Mass drug administration for lymphatic filariasis elimination in a coastal state of India: a study on barriers to coverage and compliance. Infect Dis Poverty. 2014;3:31.

31. Njomo DW, Amuyunzu-Nyamongo M, Magambo JK, Njenga SM. The role of personal opinions and experiences in compliance with mass drug administration for lymphatic filariasis elimination in Kenya. PLoS One. 2012;7(11):e48395.

32. Babu BV, Kar SK. Coverage, compliance and some operational issues of mass drug administration during the programme to eliminate lymphatic filariasis in Orissa, India. Trop Med Int Health. 2004;9(6):702-709.
33. Krentel A, Fischer PU, Weil GJ. A review of factors that influence individual compliance with mass drug administration for elimination of lymphatic filariasis. PLoS Negl Trop Dis. 2013;7(11):e2447.

34. Nujum ZT, Remadevi S, Nirmala C, Rajmohanan K, Indu P, Nair SM. Factors determining noncompliance to mass drug administration for lymphatic filariasis elimination. Trop Parasitol. 2012;2(2): 109-115.

35. Adhikari B, Phommasone K, Pongvongsa T, et al. Factors associated with population coverage of targeted malaria elimination (TME) in southern Savannakhet Province, Lao PDR. Malar J. 2017;16(1):424.

36. Adhikari RK, Sherchand JB, Mishra SR, et al. Factors determining non-compliance to mass drug administration for lymphatic filariasis elimination in endemic districts of Nepal. J Nepal Health Res Counc. 2014;12(27):124-129.
Risk Management and Healthcare Policy

\section{Publish your work in this journal}

Risk Management and Healthcare Policy is an international, peer-reviewed open access journal focusing on all aspects of public health, policy, and preventative measures to promote good health and improve morbidity and mortality in the population. The journal welcomes submitted papers covering original research, basic science, clinical and epidemiological

\section{Dovepress}

studies, reviews and evaluations, guidelines, expert opinion and commentary, case reports and extended reports. The manuscript management system is completely online and includes a very quick and fair peerreview system, which is all easy to use. Visit http://www.dovepress.com/ testimonials.php to read real quotes from published authors.

Submit your manuscript here: https://www.dovepress.com/risk-management-and-healthcare-policy-journal 